\title{
Smooth Crabgrass Control in Perennial Ryegrass with Repeated Low Fenoxaprop Application Rates
}

\author{
P.H. Demoeden ${ }^{1}$, M.J. Mahoney ${ }^{2}$, and M.J. Carroll ${ }^{3}$ \\ Department of Agronomy, University of Maryland, College Park, \\ MD 20742 \\ Additional index words. Digitaria ischaemum, Lolium perenne
}

Abstract. Fenoxaprop $\left(0.027,0.036\right.$, and $\left.0.045 \mathrm{~kg} \cdot \mathrm{ha}^{-1}\right)$ was field-applied at either of 2-, 3-, or 4-week intervals to perennial ryegrass (Lolium perenne $L_{\text {.) }}$ naturally infested with smooth crabgrass [Digitaria ischaemum (Schreb.) Muhl.] in Maryland (Easton and Silver Spring) during 1989 and 1990. In 1989, fenoxaprop applied at 2- or 3-week intervals at $0.027 \mathrm{~kg} \cdot \mathrm{ha}^{-1}$ provided fair $(>74 \%)$ to good $(>80 \%)$ smooth crabgrass control. Fenoxaprop applied at 0.036 or $0.045 \mathrm{~kg}^{-1} \mathrm{ha}^{-1}$ at 2- or 3- week intervals provided good to excellent (> 90\%) smooth crabgrass control. Four-week intervals generally provided control that was inferior to the shorter application intervals at Silver Spring but not at Easton. In 1990, all rates provided good to excellent smooth crabgrass control when applied at 2- or 3-week intervals in Easton. At Silver Spring, where smooth crabgrass levels were very high, $>88 \%$ control was provided by $0.036 \mathrm{~kg}^{-h^{-1}}$ applied at a 2-week interval and by $0.045 \mathrm{~kg} \cdot \mathrm{ha}^{-1}$ applied at either a 2- or 3-week interval. Chemical name used: $[ \pm]-2-[4-[(6$ chloro-2 benzoxazolyl)oxy]phenoxy] propanoic acid (fenoxaprop).

Recommended use rates of postemergence annual grass weed herbicides are generally

Received for publication 28 Oct. 1991. Accepted for publication 3 Apr. 1992. Scientific Article no. A 6317 and Contribution no. 8492 of the Maryland Agr. Expt. Sta. The cost of publishing this paper was defrayed in part by the payment of page charges. Under postal regulations, this paper therefore must be hereby marked advertisement solely to indicate this fact.

${ }^{1}$ Professor.

${ }^{2}$ Field Technical Representative, Hoechst-Roussel Agri-Vet Co., Oxford, MD 21654.

${ }^{3}$ Assistant Professor. too phytotoxic to apply to herbicide-sensitive species such as creeping bentgrass (Agrostis palustris Huds.) (Bhowmik and Echenlaub, 1986; Dernoeden, 1989b). When soil moisture is adequate, fenoxaprop effectively controls tillered smooth crabgrass at rates ranging from 0.20 to $0.40 \mathrm{~kg} \cdot \mathrm{ha}^{-1}$ (Bhowmik, 1986; Dernoeden and Fry, 1986; Neal et al., 1990; Watschke, 1985); however, these rates may severely injure creeping bentgrass and other sensitive species such as bermudagrass $(C y$ nodon spp.) (Bhowmik and Echenlaub, 1986; Demoeden, 1989a, 1989b). The $0.04 \mathrm{~kg} \cdot \mathrm{ha}^{-1}$ rate was shown previously to be relatively 
Table 1. Smooth crabgrass cover ratings as influenced by fenoxaprop rates and spray intervals at Silver Spring and Easton, Md.

\begin{tabular}{|c|c|c|c|c|c|c|}
\hline \multirow{3}{*}{$\begin{array}{l}\text { Fenoxaprop } \\
\text { rate } \\
\left(\mathrm{kg} \cdot \mathrm{ha}^{-1}\right) \\
\end{array}$} & \multirow{3}{*}{$\begin{array}{c}\text { Spray } \\
\text { interval } \\
\text { (weeks) }\end{array}$} & \multirow{3}{*}{$\begin{array}{c}\text { Total } \\
\text { fenoxaprop } \\
\text { applied } \\
\left(\mathrm{kg} \cdot \mathrm{ha}^{-1} \cdot \mathrm{yr}^{-1}\right)\end{array}$} & \multicolumn{4}{|c|}{ Crabgrass cover ${ }^{2}(\%)$} \\
\hline & & & \multicolumn{2}{|c|}{ Silver Spring } & \multicolumn{2}{|c|}{ Easton } \\
\hline & & & 1989 & 1990 & 1989 & 1990 \\
\hline 0.027 & & & 25 & 21 & 10 & 4 \\
\hline 0.036 & & & 16 & 25 & 6 & 8 \\
\hline 0.045 & & & 11 & 7 & 5 & 8 \\
\hline \multirow[t]{4}{*}{$\operatorname{LSD}(0.05)$} & & & 10 & 9 & NS & NS \\
\hline & 2 & & 13 & 14 & 5 & 5 \\
\hline & 3 & & 7 & 21 & 9 & 7 \\
\hline & 4 & & 33 & $\ldots y$ & 7 & $\ldots-y$ \\
\hline $\operatorname{LSD}(0.05)$ & & & 10 & NS & NS & NS \\
\hline \multirow[t]{3}{*}{0.027} & 2 & 0.135 & 23 & 26 & 9 & 3 \\
\hline & 3 & 0.108 & 12 & 16 & 12 & 5 \\
\hline & 4 & 0.081 & 41 &.$-- y$ & 10 & $\ldots y$ \\
\hline \multirow{3}{*}{0.036} & 2 & 0.180 & 6 & 10 & 3 & 8 \\
\hline & 3 & $0.144^{x}$ & 6 & $41^{x}$ & 9 & 8 \\
\hline & 4 & 0.108 & 37 & $\ldots y$ & 6 & $\ldots y$ \\
\hline \multirow[t]{3}{*}{0.045} & 2 & 0.225 & 9 & 6 & 5 & 8 \\
\hline & 3 & 0.180 & 2 & 8 & 7 & 7 \\
\hline & 4 & 0.135 & 21 & $--y^{\prime}$ & 5 & $-y^{\prime}$ \\
\hline & & & 17 & 15 & 8 & NS \\
\hline Untreated control & & & 82 & 83 & 44 & 58 \\
\hline \multicolumn{2}{|c|}{ SE } & & 6 & 4 & 7 & 4 \\
\hline
\end{tabular}

${ }^{\mathrm{z}}$ Smooth crabgrass cover was assessed visually on 1 Sept. 1989 and 31 Aug. 1990 at Silver Spring, and 28 July 1989 and 6 Aug. 1990 at Easton.

${ }^{\mathrm{y}}$ The 4-week spray interval was not evaluated in 1990.

${ }^{\mathrm{x}}$ The third of four fenoxaprop applications at $0.036 \mathrm{~kg} \cdot \mathrm{ha}^{-1}$ for the 3-week spray frequency was inadvertently missed at Silver Spring in 1990. The total amount of fenoxaprop applied for this treatment at Silver Spring in 1990 was $0.10 \% \mathrm{~kg} \cdot \mathrm{ha}^{-1}$.

safe to apply to creeping bentgrass (Bhowmik and Echenlaub, 1986; Dernoeden, 1989 b), but the ability of this rate to control smooth crabgrass has not been determined. Hence, the objective of this study was to evaluate the ability of fenoxaprop to control smooth crabgrass when applied at low rates.

Treatments were initiated on $26 \mathrm{Apr}$. and 8 May 1989 and on 1 and 2 May 1990 in Easton and Silver Spring, respectively. Fenoxaprop was applied at $0.027,0.036$, and $0.045 \mathrm{~kg} \cdot \mathrm{ha}^{-1}$ at 2-, 3-, and 4-week intervals in 1989, and at 2- and 3-week intervals in 1990. During 1989, five 2-week, four 3-week, and three 4-week interval applications were made; whereas five 2-week and four 3-week interval applications were made during 1990. The total amount of fenoxaprop applied for each treatment is shown in Table 1. Smooth crabgrass was in the one- to two-leaf stage on the initial application date at both sites. The third 3-week spray interval for the 0.036 $\mathrm{kg} \cdot \mathrm{ha}^{-1}$ rate, however, was inadvertently missed at Silver Spring in 1990. These studies were conducted on an established perennial ryegrass stand comprised of unknown cultivars maintained at a $20-\mathrm{mm}$ height in Easton and a 30-mm height in Silver Spring.

Herbicide-treated and untreated plots were arranged in a randomized complete-block design with four replicates. Individual plots were $1.5 \times 1.5 \mathrm{~m}$. Herbicide applications were made with a $\mathrm{CO}_{2}$-pressurized backpack sprayer equipped with either 8003 (Easton) or 8004 (Silver Spring) flat fan nozzles and calibrated to deliver 308 liters $\mathrm{ha}^{-1}$ at 207 $\mathrm{kPa}$ in Easton, and 467 liters $\cdot \mathrm{ha}^{-1}$ at $262 \mathrm{kPa}$ in Silver Spring. At Silver Spring, soil was a Chillum silt loam (fine silty, mixed, Mesic Typic Hapludult) with a $\mathrm{pH}$ of 6.8 and 17 mg organic matter/g of soil; whereas the ryegrass at Easton was grown on a Matapeake loam (fine silty, mixed, Mesic Typic Hapludult) with a $\mathrm{pH}$ of 5.7 and $34 \mathrm{mg}$ organic matter/g of soil. Percent smooth crabgrass cover was evaluated visually on the dates noted in Table 1 on a $0 \%$ to $100 \%$ linear scale where $0=$ no crabgrass and $100=$ entire plot area covered by crabgrass. Percentage of control was calculated by dividing the mean smooth crabgrass cover in fenoxaprop-treated plots by the mean crabgrass cover in untreated plots. An excellent level of control was considered to be $\approx 90 \%$. Data were subjected to analyses of variance, and significantly different means were separated using the least significant difference test at $P=0.05$.

1989 results. Smooth crabgrass cover ratings were higher in untreated plots at Silver Spring $(82 \%)$ than at Easton $(44 \%)$ in 1989. There was a significant rate and interval response at Silver Spring but not at Easton (Table 1). Smooth crabgrass control was better at Silver Spring in plots treated with 0.045 $\mathrm{kg}$ fenoxapropiha at either a 2- or 3-week spray interval than when sprayed every 4 weeks at $0.027 \mathrm{~kg} \cdot \mathrm{ha}^{-1}$. Except for 0.027 $\mathrm{kg} \cdot \mathrm{ha}^{-1}$ sprayed every 2 weeks, all treatments applied at either a 2- or 3-week interval at Silver Spring generally provided superior control to all 4-week interval treatments. For both sites, fair to good control ( $72 \%$ to $86 \%$ ) was provided by $0.027 \mathrm{~kg} \cdot \mathrm{ha}^{-1}$ applied on the 2- and 3-week spray interval; whereas control was poor to fair $(50 \%$ to $77 \%)$ at the 4-week interval. Excellent control $(>90 \%)$ was provided by $0.036 \mathrm{~kg} \cdot \mathrm{ha}^{-1}$ applied every 2 weeks; but good to excellent $(80 \%$ to $92 \%)$ control was provided at both sites at the 3-week interval. When 0.036 $\mathrm{kg} \cdot \mathrm{ha}^{-1}$ was applied every 4 weeks, it provided good control $(87 \%)$ at Easton, but poor control at Silver Spring (55\%). The high rate $\left(0.045 \mathrm{~kg} \cdot \mathrm{ha}^{-1}\right)$ gave good to excellent $(86 \%$ to $98 \%$ ) control when applied every 2 or 3 weeks, and fair to good ( $74 \%$ to $88 \%$ ) control when applied every 4 weeks at both locations.

Results from 1989 suggested that 0.036 $\mathrm{kg} \cdot \mathrm{ha}^{-1}$ applied either every 2 or 3 weeks was most promising in terms of smooth crabgrass control and potential safety to sensitive turfgrass species. However, 0.045 $\mathrm{kg} \cdot \mathrm{ha}^{-1}$ applied at either 2- or 3-week intervals provided superior control ( $97 \%$ to $98 \%$ ) at Silver Spring, where smooth crabgrass populations were higher.

1990 results. No 4-week spray intervals were used in 1990, primarily because of commercially unacceptable (50\% to $74 \%)$ smooth crabgrass control in 1989 with all rates at Silver Spring, where weed pressure was greater and control data were collected later in the season than at Easton.

There were no significant rate, spray interval, or rate $\times$ spray interval responses, and all treatments provided good to excellent (85\% to $96 \%$ ) smooth crabgrass control at Easton. At Silver Spring, $0.045 \mathrm{~kg} \cdot \mathrm{ha}^{-1}$ provided better smooth crabgrass control when compared with the other rates, but there was no significant spray interval response (Table 1). At Silver Spring, where there again was greater smooth crabgrass pressure, there was a rate $\times$ spray interval interaction. Fenoxaprop at $0.027 \mathrm{~kg} \cdot \mathrm{ha}^{-1}$ at Silver Spring provided poor control $(68 \%)$ at the 2 -week interval but good control $(80 \%)$ at the 3-week interval. The $0.036 \mathrm{~kg} \cdot \mathrm{ha}^{-1}$ rate provided good $(88 \%)$ smooth crabgrass control at the 2-week interval but poor $(51 \%)$ control at the 3 -week interval. Poor control with the 3 -week interval at $0.036 \mathrm{~kg} \cdot \mathrm{ha}^{-1}$ was due to the inadvertent omission of fenoxaprop on the third (i.e., 13 June) application. Excellent control (90\% to $93 \%$ ), however, was provided by $0.045 \mathrm{~kg} \cdot \mathrm{ha}^{-1}$.

These data indicate that adequate smooth crabgrass control is possible with multiple applications of low fenoxaprop rates $(0.036$ or $0.045 \mathrm{~kg} \cdot \mathrm{ha}^{-1}$ at each application). The lowest rate evaluated (i.e., $0.027 \mathrm{~kg} \cdot \mathrm{ha}^{-1}$ ) performed erratically at Silver Spring where smooth crabgrass levels were higher. To achieve season-long smooth crabgrass control, treatments must begin early in the season when crabgrass is in the one- to two-leaf stage. Herbicide applications must continue until smooth crabgrass emergence has declined to very low levels in mid- to late summer. The omission of a single scheduled spray will result in unacceptable smooth crabgrass control. Further research is required to determine the tolerance of other sensitive species and cultivars to multiple applications of fenoxaprop in the range of 0.027 to 0.045 $\mathrm{kg} \cdot \mathrm{ha}^{-1}$.

\section{Literature Cited}

Bhowmik, P.C. 1986. Fenoxaprop-ethyl for postemergence crabgrass control in Kentucky bluegrass. HortScience 21:457-458. 
Bhowmik, P.C. and M. Echenlaub. 1986. Influence of safeners on bentgrass tolerance to fenoxaprop-ethyl. Proc. Northeastern Weed Sci. Sot. 40:283. (Abstr.)

Dernoeden, P.H. 1989a. Bermudagrass suppression and zoysiagrass tolerance to fenoxaprop, p. 285-290. In: H. Takotoh (ed.). Proc. 6th Intl. Turfgrass Res. Conf., Tokyo, 31 July-5 Aug. 1989.
Demoeden, P.H. 1989b. Mature creeping bentgrass and seedling Kentucky bluegrass tolerance to fenoxaprop, p. 279-283. In: H. Takotoh (ed.). Proc. 6th Intl. Turfgrass Res. Conf., Tokyo, 31 July-5 Aug. 1989.

Dernoeden, P.H. and J.D. Fry. 1986. Postemergence control of crabgrass (Digitaria spp.) in transition zone turf with MSMA and fenoxaprop. Transportation Res. Record 1075:1-4.
Neal, J.C., P.C. Bhowmik, and A.F. Senesac. 1990. Factors influencing fcnoxaprop efficacy in cool-season turfgrass. Weed Technol. 4:272278.

Watschke, T.L. 1985. Pre- and postemergence crabgrass control in 1983 and 1984. Proc. Northeastern Weed Sci. Soc. 39:279-280. (Abstr.) 